\title{
AZ ÉSZAK-ALFÖLDI ÉS ÉSZAK-MAGYARORSZÁGI RÉGIÓKBAN FOGYATÉKOSSÁGGAL ÉLŐ TANULÓK SZABADIDÖ-ELTÖLTÉSI SZOKÁSAI
}

\author{
Laoues-Czimbalmos Nóra
}

\section{Összefoglalás}

A fogyatékossággal élö tanulók sqabadidö-eltöltési szokásait vizsgáltam, mely segithet bennünket az igények feltárásában, a fogyasz̨ói trendek kijelölésében és a motiváció megismerésében, mely a fogyatékossággal éló személyek. számára az igényfelmérésen alapuló kinálat vagy szabadidős szolgáltatás kialakitásában. A kutatást az Északalföldi és Észak magyarországi régióban végeztem, azok között a tanulók közö̈tt, akik gyógypedagógiai és integrált nevelésben-oktatásban vesznek rész̨t $(\mathrm{N}=1158)$ általános-és középfokú oktatási intézményekben. A kérdöiv kitöltetését a 2018/2019 és 2019/2020-as tanévekben a FODISZ (Fogyatékosok Országos Diáksport,-

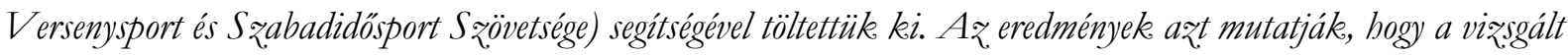
tanulók 60,4\%-a sportol këtelezó mindennapos testnevelés tanórán kiviul, azonban még mindig a passziv szabadidôs tevékenységek dominálnak, mint a zenehallgatás, tv nézés. A sportolás ösżtönzése a szabadidösportot ürö́k arányának növelése fontos, hiszen a fogyatékekal élók testi-lelki egészségének megörzését, állapotuk javitását és képességeik fejlesžtését is jelentheti.

Kulcsszavak: Fogyatékos tanulók, sұabadidö-eltöltés, passzivi-aktiv szabadidös tevékenységek, sport JEL: Z2

\section{LEISURE HABITS OF STUDENTS WITH DISABILITIES IN THE NORTHERN LANDLANDS AND NORTHERN HUNGARY REGIONS}

\begin{abstract}
I examined the leisure babits of students with disabilities, which can belp us identify needs, identify consumer trends, and learn about the motivations for developing a needs-based offer or leisure service for people with disabilities. The research was carried out in the Northern Great Plain and Northern Hungary region, among the students who participate in special education and integrated education $(N=1158)$ in primary and secondary education institutions. The questionnaire was filled in in the 2018/2019 and 2019/2020 school years with the belp of FODISZ (National Association of Student Sports, Competitive Sports and Leisure Sports for the Disabled). The results show that $60.4 \%$ of the surveyed students play sports outside of compulsory everyday physical education classes, however, passive leisure activities such as listening to music and watching TV still dominate. Encouraging sport is important to increase the proportion of people involved in recreational sports, as it can also mean maintaining the physical and mental health of people with disabilities, improving their condition and developing their skills.
\end{abstract}

Keywords: Students with disabilities, leisure, passive-active leisure activities, sports

JEL: $Z 2$ 


\section{Bevezetés}

A szabadidős tevékenységeknek fontos szerepe van az ember életében, melyet már az ókori görögök is nagyra értékeltek, hiszen a görög civilizáció volt az első, amely a szabadidőt értékként kezelte. A rekreáció a szabadidős tevékenységeket fogja csokorba, melyek akár passzív (Balogh et al. 2018; Balogh - Bácsné; 2019; Balogh et al. 2019) akár aktív formában jelennek meg mindenképp fejlesztô és pihentető szerepük van. A rekreációnak, a szabadidő hasznos és tartalmas eltöltésének talán az egyik legfontosabb momentuma, hogy biztosítja az ember egészségének és munkaképességének újratermelését. A szabadidős tevékenységek tehát az egészségvédelmet, a prevenciót vagy akár az életminőség javítását is biztosíthatják (Müller - Bácsné, 2018). Éppen ezért igen nagy jelentősége van akár az épek akár a fogyatékkal élő emberek életmódjában megjelenő szabadidős tevékenységeknek. A szabadidő-eltöltési szokások vizsgálata segíthet bennünket az igények feltárásában, a fogyasztói trendek kijelölésében és a motiváció megismerésében, mely a fogyatékossággal élő személyek számára az igényfelmérésen alapuló kínálat vagy szabadidős szolgáltatás kialakítást segíti.

\section{Irodalmi áttekintés}

A szabadidő eltöltésére irányuló kutatások a 2000-es évektől jelentek meg dominánsan a hazai és a nemzetközi szakirodalmakban, ahol a kutatások különböző aspektusból vizsgálták a rekreációt (Müller et. al. 2010; Bíró - Müller 2017; Boda et. al. 2016). Egyes kutatások a rekreáció kínálati elemeit vizsgálják, mások a keresleti oldalt, de vannak, amelyek az infrastrukturális hátterét, a menedzsment területét, a szabadidős trendeket vagy akár a rekreáció egészségre, életminőségre kifejtett hatásait teszik a vizsgálatuk középpontjába (Czeglédi et. al. 2020; Sőrés - Pető, 2015). Történeti megközelítésben a magyar pszichológia több ága is foglalkozik a szabadidő eltöltésének hasznosságával és annak mentális egészségre gyakorolt hatásaival (Molnár, 2015, 2014). Igen szép számban vannak azok a kutatások is, melyek a különböző célcsoportok rekreációs tevékenységeit vagy azokban érvényesülő trendeket vizsgálják (Müller et. al. 2017). A kutatások leginkább az épek körében végzett rekreációs tevékenységeket helyezik a kutatás középpontjába, és bár megjelentek a fogyatékossággal élő személyek rekreációját is megcélzó hazai és nemzetközi kutatások, illetve az egyes szervezeti típusokban megjelenő rekreációt támogató szervezeti elemről szóló kutatások (Molnár, 2012a,b), ám koránt sem képeznek olyan teljességre törő rendszert, mint az épekre fókuszáló rekreáció szakirodalom. A kutatások kiemelik, hogy a fogyatékossággal élő személyek számára különösen fontos a rekreációs tevékenységek fejlesztő szerepe, mely a személyes kompetenciákon túl alkalmas az állapotuk és egészségük javítására is egyben (Hidvégi - Honfi 2008, Hidvégi et. al. 2018). Fontos lenne az is, hogy a sport beépülése a mindennapokba ne csak az ép célcsoport esetében de a fogyatékossággal élő személyek számára is megvalósulhasson (Honfi et. al. 2009). Így a rekreációs tevékenységek által összességében az életminőségük pozitív változását is tapasztalhatnánk (Sőrés et al. 2012). A szabadidős tevékenységek között a fogyatékossággal élő személyek esetében is hasonló tendenciát igazoltak a kutatások, azaz leginkább a passzív szabadidőeltöltési formák dominálnak és a sportolás bár jelen van a rekreációjukban, de kevés a szabadidősportot űzők aránya (Laoues et. al. 2019a,b; Borkovics, 2019). Több tanulmány foglalkozik a szabadidős infrastruktúra akadálymentesítettségének vizsgálatával, mely a fogyatékossággal élő személyek szabadidős, sport és turisztikai létesítmények meglétét azok elérhetőségét vizsgálják (Dávid et al, 2007; Hidvégi et. al. 2018; Tatár et. al. 2019; Fitzgerald, 2018; 
Hoekstra et.al. 2019). Ezek a tanulmányok arra hívják fel a figyelmet, hogy még mindig kevés a fogyatékossággal élő személyek számára elérhetô szabadidős infrastruktúra.

\section{Anyag és módszer}

A kutatást az Észak-alföldi és Észak magyarországi régióban végeztem, azok között a tanulók között, akik gyógypedagógiai és integrált nevelésben-oktatásban vesznek részt $(\mathrm{N}=1158)$ általánosés középfokú oktatási intézményekben. A kérdőív kitöltetését a 2018/2019 és 2019/2020-as tanévekben a FODISZ (Fogyatékosok Országos Diáksport,-Versenysport és Szabadidősport Szövetsége) segítségével töltettük ki. A kérdőívek kitöltése név nélkül történt, az adatgyűjtésben való részvétel önkéntes volt. Az adatok kinyerése után SPSS statisztikai programmal elemeztem a kapott eredményeket az alapstatisztikán túl az összefüggések vizsgálatára Khí-négyzet próbát alkalmaztam. A kutatás során célom volt megvizsgálni a fogyatékosággal élő 8-18 éves tanulók szabadidő-eltöltési szokásait különös tekintettel az aktív és passzív tevékenységekre.

\section{A kutatás során az alábbiakra kerestem a választ:}

- A fogyatékossággal élő tanulók szabadidő-eltöltési szokásaiban hogyan jelenik meg a sport, mint aktív rekreációs program?

- A passzív szabadidős tevékenységek közül melyek a legnépszerúbben a fogyatékossággal élő tanulók körében?

\section{A minta bemutatása}

A válaszadók nemenkénti arányának megoszlása szerint 54,5\%-uk (631fó) fiú, 45,5\%-uk (527 fő) pedig lány. A tanulók többsége városban lakik, azaz 46,1\%-a (534 fó), megyeszékhelyen 28,3\%-a (328 fö) és községben 25,6\%-a (296 fő).

A kitöltő gyerekek 14\%-a (163 fő) alsó tagozatos tanuló. A válaszadók aránya felső tagozatban összesen 39\%-a (450 fő). A középfokú oktatásban részesülő diákokból, pedig 47\%-uk (545fő) vett rész a kutatásban. Az eredményeket a 1. táblázat szemlélteti.

\section{1. táblázat. A felmért diákok életkor megoszlása}

\begin{tabular}{|c|c|c|c|}
\hline $\begin{array}{c}\text { Hány éves } \\
\text { vagy? }\end{array}$ & Fiú (fö, \%) & Lány (fö, \%) & Összesen (fö, \%) \\
\hline \multirow{2}{*}{8} & 23 & 20 & 43 \\
\cline { 2 - 4 } & $3,60 \%$ & $3,80 \%$ & $3,70 \%$ \\
\hline \multirow{2}{*}{9} & 32 & 19 & 51 \\
\cline { 2 - 4 } & $5,10 \%$ & $3,60 \%$ & $4,40 \%$ \\
\hline \multirow{2}{*}{10} & 50 & 19 & 69 \\
\hline \multirow{2}{*}{11} & $7,90 \%$ & $3,60 \%$ & $6,00 \%$ \\
\hline \multirow{2}{*}{12} & 55 & 36 & 91 \\
\hline \multirow{2}{*}{12} & $8,70 \%$ & $6,80 \%$ & $7,90 \%$ \\
\hline & 59 & 52 & 111 \\
\hline & $9,40 \%$ & $9,90 \%$ & $9,60 \%$ \\
\hline
\end{tabular}




\begin{tabular}{|c|c|c|c|}
\hline \multirow{3}{*}{13} & 63 & 43 & 106 \\
\cline { 2 - 4 } & $10,00 \%$ & $8,20 \%$ & $9,20 \%$ \\
\hline \multirow{3}{*}{14} & 67 & 75 & 142 \\
\cline { 2 - 4 } & $10,60 \%$ & $14,20 \%$ & $12,30 \%$ \\
\hline \multirow{3}{*}{15} & 78 & 54 & 132 \\
\cline { 2 - 4 } & $12,40 \%$ & $10,20 \%$ & $11,40 \%$ \\
\hline \multirow{3}{*}{16} & 66 & 60 & 126 \\
\cline { 2 - 4 } 17 & $10,50 \%$ & $11,40 \%$ & $10,90 \%$ \\
\hline \multirow{3}{*}{18} & 59 & 62 & 121 \\
\hline \multirow{3}{*}{18} & $9,40 \%$ & $11,80 \%$ & $10,40 \%$ \\
\hline \multirow{2}{*}{ Összesen: } & 79 & 87 & 166 \\
\cline { 2 - 4 } & $12,50 \%$ & $16,50 \%$ & $14,30 \%$ \\
\hline & 631 & 527 & 1158 \\
\hline
\end{tabular}

Forrás: A Szerző", 2021

\section{Fogyatékossági típusra vonatkozó adatok}

A kutatásban a demográfiai adatok megkérdezése során, az derült ki a felmérésből, hogy a legnagyobb arányban 68,3\%-uk tanulásban akadályozott. A hallássérültek (6,3\%) és az értelmileg akadályozottak $(6,4 \%)$ kategóriájában közel azonos arányban vettek részt a kutatásban. A többi fogyatékossági ágban tartozó diák a beszédfogyatékos gyerek 8,4\%-a, a mozgáskorlátozott tanulók 7,9\%.a és a látássérültek aránya 2,7\%-a. Az eredményeket a 1. ábra szemlélteti.

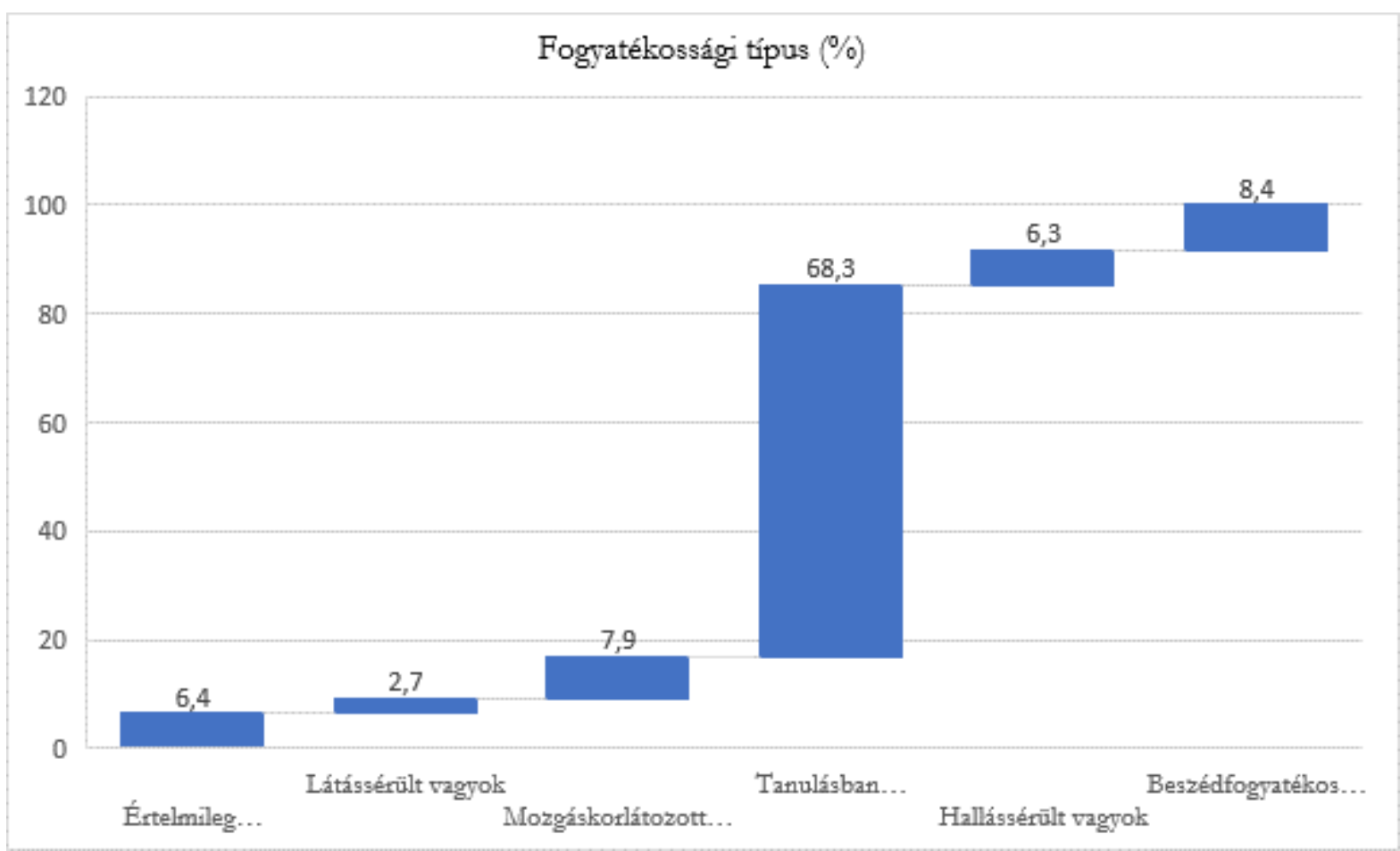

1. ábra. A felmért tanulók fogyatékos-specifikus megoszlása

Forrás: A Szerzó, 2021 


\section{Eredmények}

\section{Tanórán kívüli sport}

A diákok több mint a fele (60,4\%-uk) szokott sportolni a kötelező mindennapos testnevelés tanórán kívül, a többi (39,6\%-uk) pedig nem. A felmért tanulók nemenkénti megoszlásban szinte a fiúknál és a lányoknál is hasonlóan alakultak a válaszadási arányok. Az előbbieknél az „igen” válaszok 62,4\%-a, a „nem” válaszok 37,6\%-a, az utóbbiaknál pedig az ,igen” válaszok 57,9\%-a, a „nem” válaszok 42,1\%-a volt.

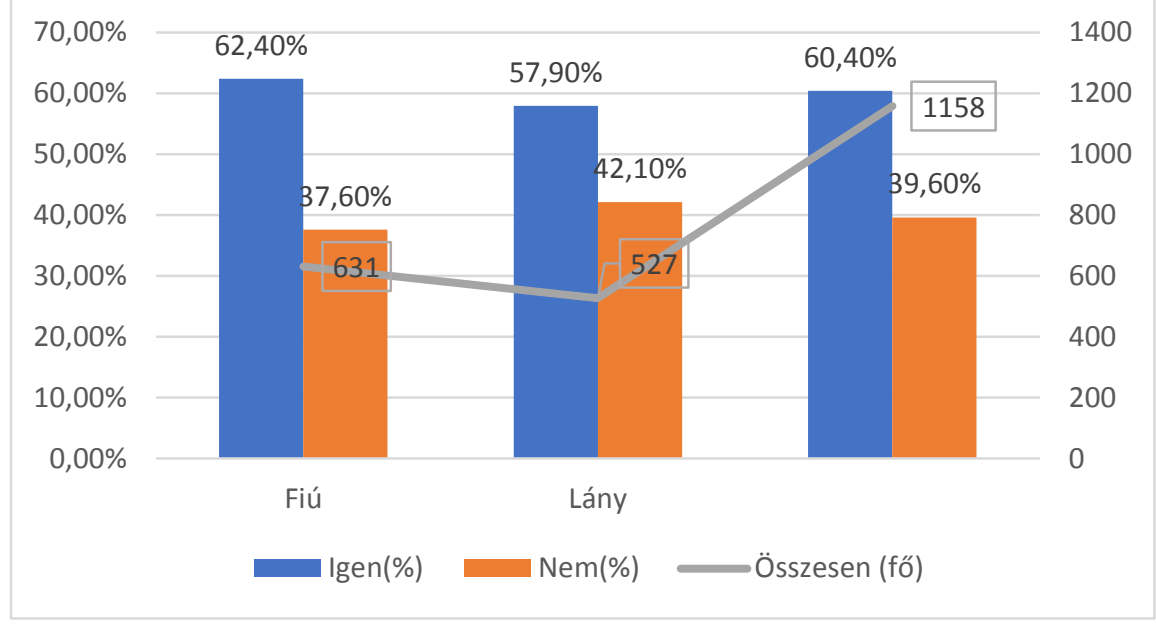

2. ábra. A válaszadók tanórán kívüli sportolási aránya és nemenkénti megoszlása Forrás: A Szerző", 2021

\section{Legnépszerübb szabadidös tevékenységek}

A beérkezett válaszok alapján elmondható, hogy leginkább a passzív szabadidő eltöltési preferencia, amely a leggyakoribb pl. a zenehallgatás a fiúknál (34,5\%), a lányoknál (40,4\%), a TV-nézés az elóbbieknél (30,9\%), az utóbbiaknál (24,3\%. A kulturális jellegű tevékenységek végzése, mint pl. a mozi, színházlátogatás $(4,8 \%)$ nem igazán volt jellemző a válaszolók körében. A Khí-négyzet-próba viszont mutatott eltérést nemenkénti megoszlásban az egyes szabadidő eltöltési tevékenységekben. A felmért tanulók tévézési szokásaiknál kiderült, hogy a sportcsatorna nézésébén és az olvasásban a nemek között szignifikáns éltérés van $(\mathrm{p}<0,05)$. A legkevésbé kedvelt tevékenységek az önkéntesség $(0,5 \%)$, a tanulás $(2,5 \%)$, étterembe járás $(1,8 \%)$, a versenyszerű sportolás $(3,5 \%)$ és a társajáté $(6,2 \%)$ (2. táblázat).

\section{2. táblázat. A felmért diákok szabadidős preferenciáinak alakulása}

\begin{tabular}{|c|c|c|}
\hline $\begin{array}{c}\text { Mi a leggyakoribb hobbid } \\
\text { a következő 10 lehetőség } \\
\text { közül? }\end{array}$ & Fiú (fö, \%) & Lány (fö, \%) \\
\hline \multirow{2}{*}{$\begin{array}{c}\text { Étterem } \\
\text { Mozi, színház }\end{array}$} & 10 & 11 \\
\hline & $1,60 \%$ & $2,10 \%$ \\
\hline & $5,20 \%$ & $4,40 \%$ \\
\hline
\end{tabular}




\begin{tabular}{|c|c|c|}
\hline \multirow[t]{2}{*}{ Olvasás } & 34 & 81 \\
\hline & $5,40 \%$ & $15,40 \%$ \\
\hline \multicolumn{3}{|c|}{$\mathrm{P}<0,05$} \\
\hline \multirow[t]{2}{*}{ Önkéntesség } & 1 & 5 \\
\hline & $0,20 \%$ & $0,90 \%$ \\
\hline \multirow[t]{2}{*}{ Sportcsatorna } & 61 & 4 \\
\hline & $9,70 \%$ & $0,80 \%$ \\
\hline \multicolumn{3}{|c|}{$\mathrm{P}<0,05$} \\
\hline \multirow[t]{2}{*}{ Tanulás } & 14 & 15 \\
\hline & $2,20 \%$ & $2,80 \%$ \\
\hline \multirow[t]{2}{*}{ Társasjáték } & 40 & 32 \\
\hline & $6,30 \%$ & $6,10 \%$ \\
\hline \multirow[t]{2}{*}{ Televíziózás } & 195 & 128 \\
\hline & $30,90 \%$ & $24,30 \%$ \\
\hline \multirow[t]{2}{*}{ Versenyszerű sportolás } & 25 & 15 \\
\hline & $4,00 \%$ & $2,80 \%$ \\
\hline \multirow[t]{2}{*}{ Zenehallgatás } & 218 & 213 \\
\hline & $34,50 \%$ & $40,40 \%$ \\
\hline \multirow[t]{2}{*}{ Összesen } & 631 & 527 \\
\hline & $100,00 \%$ & $100,00 \%$ \\
\hline
\end{tabular}

Forrás: $A$ Sžerző, 2021

\section{Mennyire tartod fontosnak a hobbit?}

A felmért tanulók nagy része fontosnak tartja szabadidőt. Összesen 32,6\%-uk (378 fö) nagyon fontosnak tartja és 61,7\%-uk (714 fö) közepesen fontos, de 5,7\%-uk (66 fö) pedig egyáltalán nem tartja fontosnak a rekreációs tevékenységeket. Nemek vonatkozásában is hasonlóan alakultak az válaszadások aránya a 3. táblázat szemlélteti az eredményeket.

3. táblázat. A felmért tanulók véleményei a hobbi fontosságáról nemenkénti megoszlásban

\begin{tabular}{|c|c|c|c|}
\hline $\begin{array}{c}\text { Mennyire tartod } \\
\text { fontosnak a } \\
\text { hobbit? }\end{array}$ & Fiú (fó, \%) & Lány (fö, \%) & Összesen (fö, \%) \\
\hline Közepesen fontos & 401 & 313 & 714 \\
\cline { 2 - 4 } & $63,50 \%$ & $59,40 \%$ & $61,70 \%$ \\
\hline $\begin{array}{c}\text { Egyáltalán nem } \\
\text { fontos }\end{array}$ & 35 & 31 & 66 \\
\cline { 2 - 4 } & $5,50 \%$ & $5,90 \%$ & $5,70 \%$ \\
\hline Nagyon fontos & 195 & 183 & 378 \\
\cline { 2 - 4 } & $30,90 \%$ & $34,70 \%$ & $32,60 \%$ \\
\hline \multirow{2}{*}{ Összesen } & 631 & 527 & 1158 \\
\cline { 2 - 4 } & $100 \%$ & $100 \%$ & $100 \%$ \\
\hline
\end{tabular}

Forrás: $A$ Szerzőo, 2021 


\section{Köveztetések és javaslatok}

A kutatás megerôsíti, hogy a fogyatékossággal élő fiatalok körében leginkább a passzív szabadidő eltöltés dominál, melyek között a zenehallgatás a TV-nézés a legkedveltebb. Ezek a tevékenységek azonban az üléssel eltöltött idő arányát növelik, így ösztönözni kell körükben a szabadidősportot, mely az állapotuk javítását is segítheti, valamint csökkentheti az ülőidő mennyiségét. Igaz, hogy a diákoknak 60,4\%-uk szokott sportolni a kötelező mindennapos testnevelés tanórán kívül, azonban a sportolók arányát növelni szükséges. leginkább az iskolai kínálat bővítésével és ezeknek a szabadidős sportolási lehetôségeknek a népszerűsítésével.

\section{Köszönetnyilvánítás}

A publikáció elkészítését az Innovációs és Technológiai Minisztérium ÚNKP-20-3-II-de-315 kódszámú új nemzeti kiválóság programjának a nemzeti kutatási, fejlesztési és innovációs alapból finanszírozott szakmai támogatásával készült.

\section{Hivatkozott források}

[1.] Balogh R. - Dajnoki, K. - Bácsné Bába É (2018): Miért beteg a magyar futball még mindig? a magyar labdarúgás játékos piacának jellemzése. Jelenkori Társadalmi És Gazdasági Folyamatok 13 (3-4), 105-117. DOI: 10.14232/jtgf.2018.3-4.105-117

[2.] Balogh R. - Molnár A. - Müller A. - Szabados Gy. N. - Bácsné Bába É. (2019): A passzív sportfogyasztás vizsgálatának tapasztalataiból. Acta Carolus Robertus 9 (1), 35-48. DOI: 10.33032/acr.2019.9.1.35.

[3.] Balogh R. - Bácsné Bába É. (2019): Sportszövetségi intézkedések attitűdvizsgálata. Acta Carolus Robertus 9 (1), 23-33. DOI: 10.33032/acr.2019.9.1.23

[4.] Bíró M. - Müller A.(2017): Aktív pihenés, rekreáció = Active relaxation, recreation. In: Dobos A. Mika J. (szerk.) Természeti és kultúrtörténeti értékek Eger térségében $=$ Natural and cultural heritage in the Eger Region. Eger, Magyarország:Líceum Kiadó (2017) p. 164.

[5.] Boda J. E. - Herpainé Lakó J. - Váczi P. (2016): A kalandparkok gazdasági múkeödésének, elemzésének elméleti háttere. In: Juhász Gy.; Korcsmáros E.; Huszárik E. (szerk.) Korszerü szemlélet a tudományban és az oktatásban. Gazdaságtudományi szekció: Zborník medzinárodnej vedeckej konferencie Univerzity J. Selyeho - 2016 „Súcasné aspekty vedy a vzdelávania" Sekcie ekonomických vied. Komárno, Szlovákia: Selye János Egyetem. 51-64.

[6.] Borkovits M. (2019): Vidéki fogyatékekal éló tanulók szabadidôs sportolási szokásainak vizsgálata. In: Gôsi Zs.; Boros Sz.; Patakiné Bősze J. (szerk.) Sokszínű Rekreáció: Tanulmányok a rekreáció témaköréből. Budapest, Magyarország: Eötvös Loránd Tudományegyetem Pedagógiai és Pszichológiai Kar, 40-49.

[7.] Czeglédi H. O. - Lenténé Puskás A. - Müller A. - Bíró M. (2020): Az úszás, mint az egészség megőrzésének és megtartásának módszere. Különleges Bánásmód 6 (2), 35-47. DOI 10.18458/KB.2020.2.35. 
[8.] Dávid, L.-Tóth, G.-Bujdosó, Z.-Herneczky, A.(2007): A turizmus és a regionális versenyképesség kapcsolatának mutatói a Mátravidék példáján keresztül Észak-Magyarországi Stratégiai Füretek 4(1), 3-20.

[9.] Fitzgerald, H. (2018): Sport is not for all: The transformative (im) possibilities of sport for young disabled people. In Sport and physical activity across the lifespan Palgrave Macmillan, London. 175-191.

[10.] Hidvégi P. - Honfi L. (2008): Fogyatékos személyek rekreációja. Acta Academiae Paedagogicae Agriensis Nova Series: Sectio Sport 35. 21-36.

[11.] Hidvégi, P. - Bíró, M.; Lenténé, Puskás A. - Tatár, A. -Pucsok, M. J. (2018): The role of physical activity among people with disabilities. In: Jaromír, Šimonek; Beáta, Dobay (szerk.) Sport science in motion: proceedings from the scientific conference. Športová veda v pohybe: recenzovaný zborník vedeckých a odborných prác z konferencie. Mozgásban a sporttudomány: válogatott tanulmányok a konferenciáról. Komárno, Szlovákia : Univerzita J. Selyeho 281-285.

[12.] Hidvégi P. - Bíró M. - Lenténé Puskás A. - Pucsok J. M. - Tatár A. (2018): Fogyatékkeal élók turizmusának lehetöségei az Észak-alföldi régióban. In: Balogh L. (szerk.) Fókuszban az egészség. Debrecen, Magyarország: Debreceni Egyetem Sporttudományi Koordinációs Intézet, 158164.

[13.] Hoekstra, F. - Roberts, L. - van Lindert, C. - Martin Ginis, K. A. - van der Woude L. H. McColl, M. A. (2019). National approaches to promote sports and physical activity in adults with disabilities: examples from the Netherlands and Canada. Disability and rehabilitation, 41(10), 1217-1226.

[14.] Honfi L. - Szalay G. - Váczi P (2009): A sport beépülése a mindennapokba. Acta Academiae Paedagogicae Agriensis Nova Series: Sectio Sport 36, 51-63.

[15.] Laoues-Czimbalmos, N. -Dobay, B. - Müller, A. (2019b): Examination Of The Leisure TimeRelated Consumption Habits Of Young People With Disabilities With Special Emphasis On Sports. Selye E-Studies 10(2), 34-45.

[16.] Laoues-Czimbalmos N. - Müller A. - Bácsné Bába É. (2019a): Fogyatékossággal Élő gyerekek Sport-Fogyasztási Szokásainak Vizsgálata Az Akadálymentesített Kínálati Elemek Tükrében. Economica(Szolnok) 10(1), 21-29. DOI: 10.47282/ECONOMICA/2019/10/1/4116.

[17.] Molnár E. (2012a): Az Osztojkán Béla Roma Szakkollégium a Szolnoki Főiskolán. Economica (Szolnok) 5:Különszám, 24-28.

[18.] Molnár E. (2014): A pszichológia filozófiai-társadalomtudományi vonalának kibontakozása Magyarországon az 1900-as években. Economica (S zolnok) 7(2,) 60-67.

[19.] Molnár E. (2015): A pszichológia természettudományos vonalának kibontakozása Magyarországon az 1900-as években. Economica (S rolnok) 8 (4/1), 124-136.

[20.] Molnár E. ; Lukács Á. (2012b): Esélyegyenlőség a közszférában egy államilag támogatott felsőoktatási intézmény példáján keresztül. Szolnoki Tudományos Közlemények 16, 496-512.

[21.] Müller A. - Bácsné Bába É. (2018): Az egészséges életmód és a sport kapcsolata. Létavértes, Magyarország: Létavértes SC '97 Egyesület. 96

[22.] Müller A. - Bíró M. - Bodolai M. - Hidvégi P. - Váczi P. - Dávid L. - Szántó Á. (2017): A 2016-os fitnesztrendek helye és szerepe a rekreációban. Acta Academiae Paedagogicae Agriensis Nova Series: Sectio Sport 44, 91-102.

[23.] Müller A. - Seres J. -Széles - Kovács Gy. - Kristonné Bakos M. - Váczi, P. (2010): Az animátorok szerepe az egészségturizmus területén. Acta Academiae Paedagogicae Agriensis Nova Series: Sectio Sport 37, 75-86.

[24.] Sôrés, A. - Pető, K. (2015): Measuring of subjective quality of life, Procedia Economics and Finance, 32, 809-816. 
[25.] Sőrés, A. - Pető, K., - Csipkés, M. (2012): Examining Life Quality in Hajdúszoboszló Tourist Area, with a Special Focus on Health Conditions, Journal of Agricultural Informatics, 3, (1), 1-10.

[26.] Tatár, A. - Lenténé, Puskás A. - Biró, M. - Pucsok, M. J. - Hidvégi, P. (2019): Accessible tourism services in the North Great Plain region. Különleges Bánásmód 5 (1),77-81. Paper: DOI 10.18458/KB.2019.1.77

\section{Szerző}

Laoues-Czimbalmos Nóra

tanársegéd

Debreceni Egyetem Gyermeknevelési és Gyógypedagógiai Kar

laoues.nora@ped.unideb.hu 